\title{
НАСІННЄВА ПРОДУКТИВНІСТЬ ТА ПАРАМЕТРИ АДАПТИВНОСТІ СОРТІВ ГОРОХУ ПОСІВНОГО ЗАЛЕЖНО ВІД ІНОКУЛЯНТІВ ТА СИСТЕМ ЗАХИСТУ РОСЛИН
}

\author{
ВОЖЕГОВА Р.А. - доктор сільськогосподарських наук, професор, \\ академік Національної академії аграрних наук України \\ https://orcid.org/0000-0002-3895-5633 \\ Інститут зрошуваного землеробства НААН \\ СоРОкУнськИЙ С.С. - аспірант \\ https://orcid.org/0000-0001-8762-012X \\ Інститут зрошуваного землеробства НАAН
}

Постановка проблеми. сучасна технологія вирощування гороху, і насамперед удосконалена, може забезпечити високий рівень продуктивності, передбачає ефрективне використання мінеральних добрив, засобів захисту посівів від бур'янів, шкідників та хвороб, проте ці технології недостатньо адаптовані до кліматичних змін і стрес-фракторів. Проблема підвищення урожайності гороху $€$ важливою для народного господарства України. Не менш актуальним є завдання підвищення економічної ефективності його виробництва, оскільки в останні роки цій культурі мало приділялось уваги. Тому необхідно розробляти й упроваджувати нові підходи, особливо з точки зору пристосування окремих агротехнологічних чинників до певних погодних умов та посилення адаптивної здатності сортів [1, 2].

Аналіз останніх досліджень і публікацій. У сучасних умовах ведення сільського господарства важливою вимогою до елементів технології, які розробляються та впроваджуються у виробництво, в тому числі і для гороху, є підвищення врожайності, якості зерна, а також адаптивних характеристик, які відображають стійкість сортотипів до певних ґрунтово-кліматичних умов. Основним завданням агропромислового комплексу України $є$ формування ринкових механізмів, які здатні бути стимулюючим чинником економічного прогресу, змушували суб'єкти господарської діяльності відновлювати й у подальшому нарощувати обсяги сільськогосподарського виробництва, спонукав освоювати нові технології виробництва продукції і відмовлятися від застарілих, боротися за зниження собівартості продукції і підвищення рентабельності [4].

В дослідах з насінництва велике значення має встановлення параметрів адаптивності певних сортів і гібридів до випливу несприятливих метеорологічних та інших умов, які характерні для конкретної зони вирощування. За результатами досліджень вітчизняних і закордонних вчених встановлено, що основна цінність нового сорту (гібриду) повинна визначатися величиною гомеостатичності врожаю та якості продукції для певного зони, регіону, локальної території [5]. Для практичної селекційної оцінки сортів (гібридів) і селекційних ліній найбільш придатний показник селекційної цінності (Sc), тим паче, що для його визначення не має потреби обчислювати дисперсії, а можна користуватися лише даними суцільного обліку врожаю з дослідної ділянки. Показник селекційної стійкості $(\mathrm{Hom})$ найбільш придатний в першу чергу для генетичних досліджень, проте він може також використовуватись для селекційної роботи та в насінництві - для встановлення реакції сортів (гібридів) на стрес-срактори [6].

Матеріал і методи досліджень. Метою досліджень було встановити вплив агротехнологічних фракторів та погодних умов в окремі роки досліджень на врожайність насіння та параметри адаптивності культури за вирощування на неполивних землях Південного Степу України.

Дослідження проводились упродовж 2018-2020 років на дослідному полі Інституту зрошуваного землеробства НААН. Польові досліди закладалися методом розщеплених ділянок у чотириразовій повторності згідно методики дослідної справи в агрономії [7]. Параметри адаптивності розраховували згідно спеціальних методик $[5,6]$. Схема досліду представлено в таблицях статті. Агротехніка вирощування насіння гороху посівного в дослідах була загальновизнаною для умов півдня України.

Результати досліджень. За результатами досліджень встановлено, що в роки проведення досліджень врожайність насіння гороху посівного значною мірою залежала від особливостей погодних умов, у першу чергу - від кількості опадів у вегетаційний період. В середньому за роки досліджень цей показник відповідно становив за сортовим складом: Царевич - 2,19 т/ га; Дарунок Степу - 2,08; Отаман - 1,89; Світ - 1,75; Оплот - 1,70 т/га (табл. 1). Порівняно $з$ найбільшим значенням врожайності на сорті Царевич проявилось зниження іiї на 5,3\%, 15,9, 25,1 і 28,8\%, відповідно, ілюструючи значущість підбору сортового складу при вирощуванні досліджуваної культури.

Інокуляція насіння перед сівбою (фактор В) була ефективнішою у варіанті з Біогелем, але його перевага перед АМК не характеризувалася високою статистичною значущістю. Так, скажімо, за вирощування гороху Світ врожайність зросла на 6,9\%, Дарунок Степу $-4,1$, Отаман $-4,5$, Царевич $-3,4$, Оплот - 3,3\%. Зауважимо, що у варіанті без захисту провідним фрактором врожайності був сорт продукції. Так, наприклад, вирощування гороху Царевич у таких умовах забезпечило врожайність на рівні 2,01 т/га, а у випадку з сортом Оплот аналогічне середнє значення не перевищило 1,54 т/га, ілюструючи зниження врожайності на $30,5 \%$.

Хімічний захист рослин (фактор С), як і у попередніх роках, виявився найефективнішим, збільшивши врожайність до 2,17 т/га, або на 38,21\% у порівнянні з варі- 
антом контролю, де середнє значення не перевищило позначки в 1,57 т/га. Результати дослідження довели, що біологічна форма захисту дещо поступається хімічній, оскільки врожайність у варіанті з біологічною обробкою знизилася до 2,02 т/га, або на 7,4\%. Водночас перевага останньої порівняно з групою контролю сягає 22,3\%, засвідчуючи її ефрективність.

Дисперсійним аналізом встановлено мінливість результативних ознак варіювання врожайності насіння досліджуваних сортів гороху залежно від інокулянтів та захисту рослин (рис. 1).

За результатами математичної обробки одержаних у польовому досліді даних визначено, що на врожайність гороху максимальною мірою впливає захист рослин - 42,8\%, на сортовий склад припадає $34,3 \%$. Інокуляція насіння меншою мірою сприяє формуванню врожайності - 10,9\%. Взаємодія досліджуваних фракторів не суттєва - у межах 0,4-1,2\%. Залишкове значення складає 9,3\%, що свідчить про суттєвий вплив неврахованих фракторів на формування врожайності гороху співного (відмінності погодних умов, вплив неврахованих агротехнічних і природних чинників).
За результатами проведених нами обчислень параметрів адаптивності визначено, що стресостійкість рослин найбільшого рівня досягнула у сорту Оплот $(-0,25)$, а мінімального значення сягнув у сорту Дарунок Степу, де він зменшився до -0,32 (табл. 2).

Генетична гнучкість максимальної величини $(2,16)$ сягнула за вирощування насіння сорту Царевич. Також високий рівень цей показник мав у варіанті з сортом Дарунок Степу - 2,06. Мінімальні значення генетичної гнучкості $(1,67-1,74)$ зафріксовані за вирощування сортів гороху посівного Оплот та Світ, що менше порівняно з сортом Царевич на 19,4-22,7\%, відповідно.

Високий рівень статистичної сталості насіннєвої продуктивності гороху забезпечив сорт Царевич, на якому коефіцієнт варіації склав 9,8\%. На інших досліджуваних сортах даний показник перевищував $10 \%$, а найбільшого рівня $(14,7 \%)$ досягнув у варіанті з сортом Отаман.

Показник гомеостатичності підвищився до 66,7 і 68,8 у варіантах з сортами Оплот та Царевич. Цей показник зменшився на 39,5-43,9\% (до 47,8) за вирощування насіння гороху сорту Світ.

Максимальна величина показника селекційної цінно-

Таблиця 1 - Урожайність гороху посівного залежно від сортового складу, інокуляції насіння перед сівбою та захисту рослин, т/га (середнє за 2018-2020р.)

\begin{tabular}{|c|c|c|c|c|c|c|}
\hline \multirow{2}{*}{$\begin{array}{c}\text { Сорт } \\
\text { (фактор A) }\end{array}$} & \multirow{2}{*}{ Інокулянт (фрактор В) } & \multicolumn{3}{|c|}{ Захист рослин (фактор С) } & \multicolumn{2}{|c|}{ Середнє по } \\
\hline & & без захисту & біоло-гічний & хімічний & B & A \\
\hline \multirow{3}{*}{ Дарунок Степу } & Контроль (вода) & 1,53 & 1,99 & 2,21 & 1,91 & \multirow{3}{*}{2,08} \\
\hline & AKM & 1,67 & 2,30 & 2,39 & 2,12 & \\
\hline & Біогель & 1,74 & 2,36 & 2,53 & 2,21 & \\
\hline \multirow{3}{*}{ Світ } & Контроль (вода) & 1,30 & 1,63 & 1,85 & 1,59 & \multirow{3}{*}{1,75} \\
\hline & AKM & 1,41 & 1,83 & 2,03 & 1,76 & \\
\hline & Біогель & 1,56 & 2,02 & 2,10 & 1,89 & \\
\hline \multirow{3}{*}{ Оплот } & Контроль (вода) & 1,32 & 1,57 & 1,75 & 1,54 & \multirow{3}{*}{1,70} \\
\hline & AKM & 1,43 & 1,86 & 1,94 & 1,74 & \\
\hline & Біогель & 1,48 & 1,91 & 2,01 & 1,80 & \\
\hline \multirow{3}{*}{ Отаман } & Контроль (вода) & 1,41 & 1,71 & 2,05 & 1,72 & \multirow{3}{*}{1,89} \\
\hline & AKM & 1,56 & 2,00 & 2,20 & 1,92 & \\
\hline & Біогель & 1,68 & 2,10 & 2,26 & 2,01 & \\
\hline \multirow{3}{*}{ Царевич } & Контроль (вода) & 1,72 & 2,07 & 2,23 & 2,01 & \multirow{3}{*}{2,19} \\
\hline & AKM & 1,87 & 2,43 & 2,44 & 2,24 & \\
\hline & Біогель & 1,87 & 2,51 & 2,57 & 2,32 & \\
\hline \multicolumn{2}{|c|}{ Середнє за фактором C } & 1,57 & 2,02 & 2,17 & & \\
\hline
\end{tabular}

Таблиця 2 - Параметри адаптивності досліджуваних сортів гороху посівного (фактор А) залежно від інокуляції насіння перед сівбою (фактор В) (середнє за 2018-2020 рр.)

\begin{tabular}{|c|c|c|c|c|c|}
\hline \multirow{2}{*}{ Сорт } & \multicolumn{5}{|c|}{ Параметри } \\
\cline { 2 - 6 } & $\begin{array}{c}\text { стресо-стійкість } \\
\mathbf{x}_{\text {lim }}-\mathbf{x}_{\text {opt }}\end{array}$ & $\begin{array}{c}\text { генетична } \\
\text { гнучкість } \\
\left(\mathbf{x}_{\text {lim }}+\mathbf{x}_{\text {opt }}\right) / 2\end{array}$ & $\begin{array}{c}\text { коефіцієнт } \\
\text { варіації } \\
\mathbf{V}, \mathbf{\%}\end{array}$ & $\begin{array}{c}\text { гомеоста-тич- } \\
\text { ність } \\
\mathbf{H}_{\text {om }}\end{array}$ & $\begin{array}{c}\text { селекційна } \\
\text { цінність } \\
\mathbf{S}_{\mathbf{c}}\end{array}$ \\
\hline Дарунок Степу & $-0,32$ & 2,06 & 12,5 & 66,7 & 1,78 \\
\hline Світ & $-0,30$ & 1,74 & 11,9 & 47,8 & 1,47 \\
\hline Оплот & $-0,25$ & 1,67 & 12,3 & 61,7 & 1,44 \\
\hline Отаман & $-0,29$ & 1,87 & 14,7 & 58,7 & 1,60 \\
\hline Царевич & $-0,31$ & 2,16 & 9,8 & 68,8 & 1,87 \\
\hline
\end{tabular}


сті проявилася за вирощування насіння сортів Царевич $(1,87)$ та Дарунок Степу $(1,78)$, а найменше ії̈ значення було виявлено у варіанті з сортом Оплот - 1,44, що на 23,6-29,8\% менше за вищезгадані сорти.

Параметри адаптивності досліджуваних сортів залежно від захисту рослин (табл. 3) у цілому відображали тенденції, що були встановлені раніше стосовно варіантів інокуляції насіння перед сівбою. Так, стресостійкістю найбільшого від'ємного рівня $(-1,00)$ досягла у варіанті з сортом Дарунок Степу. За вирощування сорту Оплот цей показник підвищився до $-0,69$ або на 44,9\%. Сорти Отаман і Царевич займали проміжне положення - у них стресостійкістю дорівнювала $-0,85$.

Генетична гнучкість зросла до 2,15 у варіанті з сортом Цесаревич. Також високим даний показник виявився у сорту Дарунок Степу - 2,03, а у варіанті з сортом Оплот сягнув мінімального рівня - 1,67, що 21,6-28,7\% менше за сорти Дарунок Степу й Царевич.

Мінливість показників врожайності насіння гороху посівного знаходилось на середньому рівні. Визначено тенденцію зниження варіювання у сортів Царевич $(10,4 \%)$ і Оплот $(14,9 \%)$ та, навпаки, зростання цього показника до 17,3\%, у варіанті з сортом Дарунок Степу.
Гомеостатичність максимальної величини 44,2 була сформована сортом Царевич, а у сорту Світ цей показник зменшився до 33,5 або на 31,9\%. Також високе значення гомеостатичності показав сорт Оплот - 41,9.

Селекційна цінність максимального значення набула у варіанті з сортом Царевич $(1,44)$, а за вирощування сорту Світ вона зменшилась на 37,1\% (до 1,05).

Висновки. У польових дослідах визначено, що максимальну врожайність насіння забезпечують сорти гороху посівного Царевич (2,19 т/га) та Дарунок Степу (2,08 т/га), а на інших сортах цей показник зменшився на 5,3-28,8\%. Інокуляція насіння при сприяла зростанню врожайності на 3,3-6,9\%, а найбільша ефективність бактеріальних біопрепаратів проявилась на сорті Царевич - до 30,5\%. Хімічний захист рослин мав найбільший позитивний вплив на величину врожайності насіння з її зростанням на $38,2 \%$ порівняно 3 контролем. За біологічного захисту відбулося зниження насіннєвої продуктивності сортів гороху на $7,4 \%$, проте цей варіант також на $22,3 \%$ вище контролю з обробкою водою. За результатами математичної обробки одержаних у польовому досліді даних визначено, що на врожайність досліджуваної культури найбільше впливає захист рослин $(42,8 \%)$ та сортовий склад $(34,3 \%)$. Взаємодія фракторів на даний показник

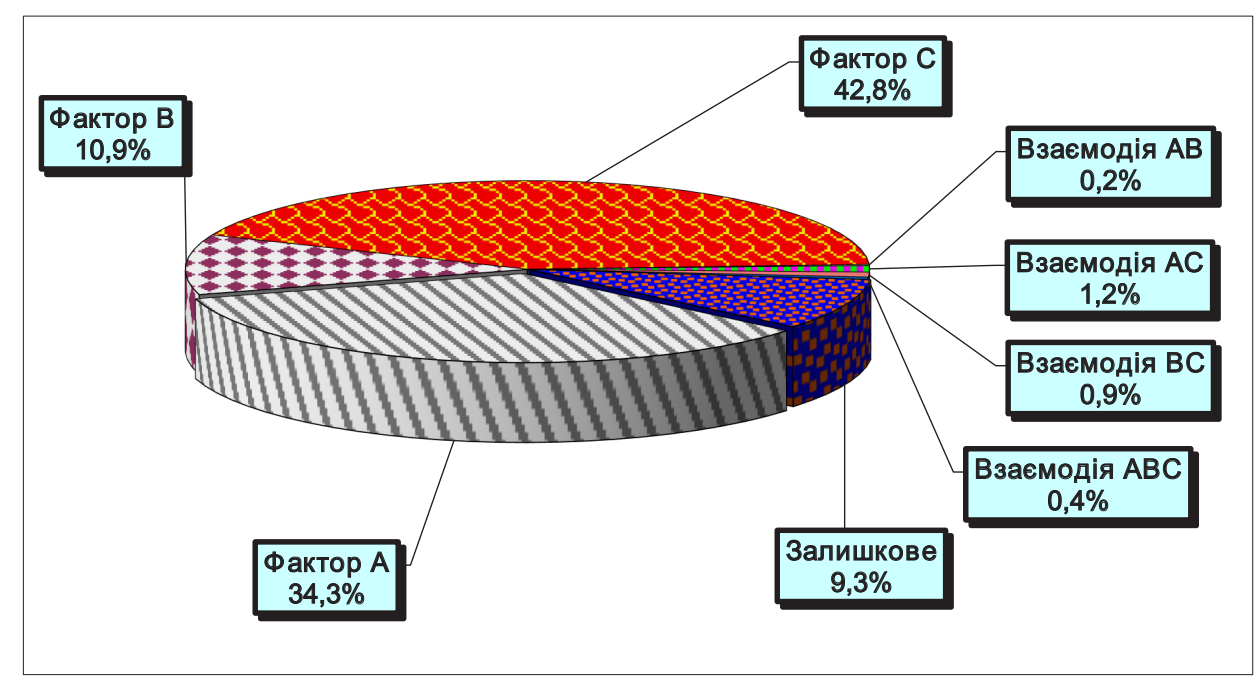

Рис. 1. Мінливість джерел варіювання (дисперсій) залежно від сортового складу (фактор А), інокуляції насіння (фактор В) та захисту рослин (фактор

С) на формування врожаю гороху посівного, \% (середнє за 2018-2020 рр.)

Таблиця 3 - Параметри адаптивності досліджуваних сортів гороху посівного (фактор А) залежно від захисту рослин (фактор С) (середнє за 2018-2020рр.)

\begin{tabular}{|c|c|c|c|c|c|}
\hline \multirow{2}{*}{ Сорт } & \multicolumn{5}{|c|}{ Параметри } \\
\cline { 2 - 6 } & $\begin{array}{c}\text { стресо-стійкість } \\
x_{\text {lim }}-x_{\text {орt }}\end{array}$ & $\begin{array}{c}\text { генетична } \\
\text { гнучкість } \\
\left(x_{\text {lim }}+x_{\text {opt }}\right) / 2\end{array}$ & $\begin{array}{c}\text { коеріцієнт варіації } \\
V, \%\end{array}$ & $\begin{array}{c}\text { гомеостатичність } \\
H_{\text {от }}\end{array}$ & $\begin{array}{c}\text { селекційна } \\
\text { цінність } \\
S_{c}\end{array}$ \\
\hline Дарунок Степу & $-1,00$ & 2,03 & 17,3 & 37,2 & 1,23 \\
\hline Світ & $-0,80$ & 1,70 & 16,4 & 33,5 & 1,05 \\
\hline Оплот & $-0,69$ & 1,67 & 14,9 & 31,9 & 1,09 \\
\hline Отаман & $-0,85$ & 1,84 & 16,0 & 44,7 & 1,14 \\
\hline Царевич & $-0,85$ & 2,15 & 10,4 & & 1,44 \\
\hline
\end{tabular}


впливала слабко, а залишкове значення, навпаки, підвищились до 9,3\%, що свідчить про істотний вплив погодних умов на продуктивність рослин. Адаптивним аналізом доведено, що стресостійкість найбільшого рівня досягнула у сорту Оплот $(-0,25)$, а генетична гнучкість максимальної величини $(2,16)$ сягнула за вирощування насіння сорту Царевич. Показник гомеостатичності підвищився до 66,7 і 68,8 у варіантах з сортами Оплот та Царевич. Цей показник зменшився на 39,5-43,9\% (до 47,8) за вирощування насіння гороху сорту Світ. Максимальна величина показника селекційної цінності проявилася за вирощування насіння сортів Царевич $(1,87)$ та Дарунок Степу $(1,78)$. Мінливість показників врожайності насіння гороху посівного знаходилось на середньому рівні. Визначено тенденцію зниження варіювання у сортів Царевич $(10,4 \%)$ і Оплот $(14,9 \%)$ та, навпаки, зростання цього показника до 17,3\%, у варіанті з сортом Дарунок Степу.

\section{СПИСОК ВИКОРИСТАНОÏ ЛІТЕРАТУРИ:}

1. Лимар А. О., Лимар В. А., Коковіхін С. В., Домарацький $€$. О. Агрокліматичні ресурси півдня України та їх раціональне використання: монографія. Херсон: Грінь Д.С., 2015. 246 с.

2. Бабич А. А. Світові земельні, продовольчі і кормові ресурси. Київ: Аграрна наука, 1996. 570 с.

3. Капінос М.В. Агроекономічна та енергетична оцінка елементів технології вирощування сортів гороху в умовах Південного Степу України. Зрошуване землеробство: міжвід. темат. наук. зб. Херсон: ОЛДІПЛЮС, 2019. Вип. 72. С. 135-138.

4. Лавриненко Ю. О., Коковіхін С. В., Ларченко О.В., Влащук А. М. Економічна оцінка елементів технології вирощування пшениці в умовах південного Степу України. Таврійський науковий вісник. 2009. Вип. 68.С. 12-20.

5. Хангильдин В. В., Бирюков С. В. Проблема гомеостаза в генетико-селекционных исследованиях. Генетико-цитологические аспекты в селекции с.-х. растений. 1984. № 1. С. 67-76.

6. Сапега В. А. Урожайность и параметры адаптивности сортов зерновых культур в Лесостепи Северного Зауралья. Доклады РАСХН. 2010. №3. С. 10-14.

7. Ушкаренко В. О., Вожегова Р. А., Голобородько С. П., Коковіхін С. В. Методика польового досліду (зрошуване землеробство) : навчальний посібник. Херсон: Грінь Д. С., 2014. 448 с.

\section{REFERENCES:}

1. Lymar, A.O., Lymar, V.A., Kokovikhin, S.V., \& Domarats'kyy, Ye.O. (2015). Ahroklimatychni resursy pivdnya Ukrayiny ta yikh ratsional'ne vykorystannya [Agroclimatic resources of the south of Ukraine and their rational use]. Kherson: Grin D. S. [in Ukrainian].

2. Babych, A.A. (1996). Svitovi zemelni, prodovolchi kormovi resursy [World land, food and feed resources]. Kyiv: Agrarian Science [in Ukrainian].

3. Kapinos, M.V.(2019). Ahroekonomichnata enerhetychna otsinka elementiv tekhnolohiyi vyroshchuvannya sortiv horokhu $v$ umovakh Pivdennoho Stepu Ukrayiny [Agroeconomic and energy assessment of elements of pea cultivation technology in the conditions of the Southern Steppe of Ukraine]. Irrigated agriculture, 72, 135-138 [in Ukrainian].
4. Lavrynenko, Yu.O., Kokovikhin, S.V., Larchenko, O.V., \& Vlashchuk, A.M. (2009). Ekonomichna otsinka elementiv tekhnolohiyi vyroshchuvannya pshenytsi $v$ umovakh pivdennoho Stepu Ukrayiny [Economic evaluation of elements of wheat cultivation technology in the conditions of the southern steppe of Ukraine]. Taurian Scientific Journal: Scientific Collection, 68, 12-20 [in Ukrainian].

5. Khangildin, V.V. \& Biryukov, S.V. (1984). Problema gomeostaza $v$ genetiko-selektsionnykh issledovaniyakh [The problem of homeostasis in genetic selection studies]. Genetic and cytological aspects in the selection of agricultural animals. Plants, 1, 67-76 [in Russia].

6. Sapega, V.A. (2010). Urozhaynost i parametry adaptivnosti sortov zernovykh kultur v Lesostepi Severnogo Zauralya [Productivity and adaptability parameters of grain varieties in the forest-steppe of the Northern Trans-Urals]. Reports of the Russian Academy of Agricultural Sciences, 3, 10-14 [in Russia].

7. Ushkarenko, V.O., Vozhegova, R.A., Goloborodko, S.P. \& Kokovikhin, S.V. (2014). Metodyka polyovoho doslidu (zroshuvane zemlerobstvo) [Methods of field experiment (irrigated agriculture)]. Kherson: Grin D. S. [in Ukrainian].

Вожегова Р. А., Сорокунський С. С. Насіннєва продуктивність та параметри адаптивності сортів гороху посівного залежно від інокулянтів та систем захисту рослин

Мета - встановити вплив агротехнологічних факторів та погодних умов в окремі роки досліджень на врожайність насіння та параметри адаптивності культури за вирощування на неполивних землях Південного Степу України. Методи. Польовий, статистичний. Результати. Встановлено, що біологічного захисту відбулося зниження насіннєвої продуктивності сортів гороху на 7,4\%, проте цей варіант також на 22,3\% вище контролю з обробкою водою. За результатами математичної обробки одержаних у польовому досліді даних визначено, що на врожайність досліджуваної культури найбільше впливає захист рослин $(42,8 \%)$ та сортовий склад $(34,3 \%)$. Взаємодія факторів на даний показник впливала слабко, а залишкове значення, навпаки, підвищились до 9,3\%, що свідчить про істотний вплив погодних умов на продуктивність рослин. Адаптивним аналізом доведено, що стресостійкість найбільшого рівня досягнула у сорту Оплот $(-0,25)$, а генетична гнучкість максимальної величини $(2,16)$ сягнула за вирощування насіння сорту Царевич. Висновки. У польових дослідах визначено, що максимальну врожайність насіння забезпечують сорти гороху посівного Царевич (2,19 т/га) та Дарунок Степу (2,08 т/га), а на інших сортах цей показник зменшився на 5,3-28,8\%. Інокуляція насіння при сприяла зростанню врожайності на 3,3-6,9\%, а найбільша ефективність бактеріальних біопрепаратів проявилась на сорті Царевич - до 30,5\%. Хімічний захист рослин мав найбільший позитивний вплив на величину врожайності насіння з її зростанням на $38,2 \%$ порівняно з контролем. Показник гомеостатичності підвищився до 66,7 і 68,8 у варіантах з сортами Оплот та Царевич. Цей показник зменшився на 39,5-43,9\% (до 47,8) за вирощування насіння гороху сорту Світ. Максимальна величина показника селекційної цінності проявилася за вирощування насіння сортів Царевич $(1,87)$ та Дарунок Степу $(1,78)$. Мінливість показників врожайності насіння гороху посівного знаходилось на середньому рівні. Визначено 
тенденцію зниження варіювання у сортів Царевич $(10,4 \%)$ і Оплот $(14,9 \%)$ та, навпаки, зростання цього показника до 17,3\%, у варіанті з сортом Дарунок Степу.

Ключові слова: горох посівний, насіння, сорт, інокулянт, захист рослин, врожайність, адаптивність.

Vozhehova R. A., Sorokunsky S. S. Seed productivity and adaptability parameters of pea varieties depending on inoculants and plant protection systems

Goal. The aim is to establish the influence of agrotechnological factors and weather conditions in certain years of research on seed yield and parameters of crop adaptability for cultivation on non-irrigated lands of the Southern Steppe of Ukraine.

Methods. Field, statistical. Results. It was found that the biological protection of the seed productivity of pea varieties decreased by $7.4 \%$, but this option is also $22.3 \%$ higher than the control with water treatment. According to the results of mathematical processing of the data obtained in the field experiment, it was determined that the yield of the studied crop is most influenced by plant protection (42.8\%) and varietal composition (34.3\%). The interaction of factors had a weak effect on this indicator, and the residual value, on the contrary, increased to $9.3 \%$, which indicates a significant impact of weather conditions on plant productivity. Adaptive analysis proved that the stress resistance reached the highest level in the variety Oplot $(-0.25)$, and the genetic flexibility of the maximum value (2.16) was reached during the cultivation of seeds of the variety Tsarevich. Conclusions. In field experiments it was determined that the maximum seed yield is provided by pea varieties Tsarevich (2.19 t/ha) and Darunok Stepu $(2.08 \mathrm{t} / \mathrm{ha})$, and in other varieties this indicator decreased by $5.3-28.8 \%$. Inoculation of seeds contributed to an increase in yield by $3.3-6.9 \%$, and the greatest effectiveness of bacterial biologicals was manifested in the variety Tsarevich - up to $30.5 \%$. Chemical protection of plants had the greatest positive effect on the value of seed yield with its growth by $38.2 \%$ compared to the control. The homeostatic index increased to 66.7 and 68.8 in the variants with Oplot and Tsarevich varieties. This figure decreased by $39.5-$ $43.9 \%$ (to 47.8 ) for growing pea seeds of the World variety. The maximum value of the selection value was manifested in the cultivation of seeds of the varieties Tsarevich (1.87) and the Gift of the Steppe (1.78). The variability of pea seed yields was at the average level. The tendency of decrease of variation at varieties Tsarevich (10,4\%) and Oplot (14,9\%) and, on the contrary, growth of this indicator to $17,3 \%$, in a variant with a grade the Gift of Steppe is defined.

Key words: peas, seeds, variety, inoculant, plant protection, yield, adaptability. 